\title{
THE EVALUATION OF FINANCIAL STABILITY AND SOUNDNESS OF LITHUANIAN BANKS
}

\author{
ROMUALDAS GINEVIČIUS ${ }^{a}$, ASKOLDAS PODVIEZKO ${ }^{\text {b }}$
}

aVilnius Gediminas Technical University, LT-12230 Vilnius, Sauletekioave. 11, romualdas.ginevicius@vgtu.It

b Vilnius Gediminas Technical University, LT-12230 Vilnius, Sauletekioave. 11, askoldas.podviezko@vgtu.It

\section{ARTICLE INFO}

Article data:

- Received: 20 September 2012

- Accepted: 11 January 2013

JEL classification: G10, G11, G12, C13

Keywords:

- Multiple criteria analysis

- OR in banking

- Bank soundness and stability

- CAMEL

\begin{abstract}
The successful development of economy is based on effective and stable performance of commercial banks. The evaluation of stability and soundness of banks is a complex task, involving a considerable number of multidimensional criteria. It is an idiosyncratic task because of a complicated internal business structure of banks, intertwined cash flows and strong influence of market conditions on soundness levels. In this paper, soundness and stability dynamics of commercial banks registered in Lithuania was evaluated by using several multiple criteria methods from simpler ones to the more sophisticated PROMETHEE method. The results obtained indicate that the levels of soundness and stability of banks operating in the developing Lithuanian market of commercial banks noticeably fluctuate. A comparison of the obtained results reveals the causes of the fluctuations. A simultaneous use of different multiple criteria methods for evaluating the soundness and stability of commercial banks increases the robustness of the evaluation.
\end{abstract}

Reference to this paper should be made as follows: Ginevičius, R; Podviezko, A:, 2013. The evaluation of financial stability and soundness of Lithuanian banks, Ekonomska istraživanja - Economic Research 26(2): 515-535. 


\section{INTRODUCTION.}

One of the most important factors influencing cohesive economic development of any country is effective performance and reliability of its banks. The evaluation of soundness and stability of the commercial banks and the stability of the financial system of a country are closely related (Miletic, 2009). In fact, if the evaluation reflects the influence of the contributing factors to the soundness and stability of each commercial bank in the market in formats, which are clear and understandable to groups of users, as well as adequately and promptly reflecting the reality, it considerably decreases information asymmetry in the banking sector. This in turn raises confidence of depositors in the group of stable banks (Ergungor, Thomson, 2005). The complexity of the task of evaluating the commercial banks is predetermined by the complicated internal business structure of banks, intertwined cash flows and strong influence of market conditions on soundness levels of banks, as a result, a considerable number of criteria of various dimensions is involved in the above problem solution.

The choice of evaluation techniques, applicable to the particular market of the commercial banks of a country is very important. Clear advantages of MCDA methods, branch of OR methods, become intensely evident wherever complexity is involved in creating an objective, thus considerably enhancing the risk-return modelling (Spronk, Steuer, Zopounidis, 2005). MCDA methods allow for using a wide range of multi-dimensional criteria and expressing the evaluation results in the clear form of ranking tables.

Advantages of using MCDA methods in finance are outlined by Zopounidis (1999). The MCDA approach allows for decreasing the level of subjectivity and accelerating decision-making. It provides a worthy possibility of structuring complex evaluation problems. The MCDA approach allows setting a structure to the problem of the evaluation by using quantitative criteria. Values of the criteria are expressed in quantitative terms and are extracted from the statistical data present in financial statements of commercial banks. At the next stage, the weights of the criteria are determined. Both stages of laying out of the criteria and determining their weights are based on eliciting knowledge from the employed experts, who define quantitative criteria and determine their weights in relation to the goals of the evaluation.

Hence, the uniform unequivocal framework of evaluation for the whole set of banks in question is set. The considered approach allows to make a transparent presentation and description of the evaluation method and to obtain prompt results. It is useful in making real-life decisions at minimal costs. These features are particularly valuable in the countries of the developing economy such as Lithuania, where economic parameters are fluctuating to great extent, decisions have to be made promptly, and cost of evaluation is of prime importance.

White, Smith, Currie (2011) point out that small developing countries have been overlooked by OR activities in contrast to large countries. In particular, this is true for Lithuania in the field of finance. Lithuanian scientists pay some attention to the problem of evaluating domestic banks by MCDA methods (Brauers, Ginevicius, Podviezko, 2012; Zavadskas, Kaklauskas, Banaitis, Kvederyte, 2004; Ginevicius, Podvezko, 2008a; Ginevicius, Podvezko, Novotny, 2010; Ginevicius, Podvezko, Podviezko, 2012; Zvirblis, Buracas, 2010; Podviezko, Ginevicius, 2010; Stankeviciene, Mencaite, 2012).

However, the research is fragmentary and cannot provide a clear picture of soundness and stability of local commercial banks and their dynamics. This paper aims to fill this gap.

The aim of the paper is to propose an evaluation methodology, which does not delay reporting of the banks' financial position. Criteria (variables) of evaluation are chosen to reflect 
the aspirations of depositors in terms of soundness and stability of banks. The uniform framework of evaluation decreases subjectivity of evaluation by experts, in contrast to the approach of rating agencies, when different experts evaluate different banks.

The evaluation of soundness and stability of commercial banks presented in this paper is targeted at the decision-makers representing depositors, bank managers, and comptrollers and is intended to serve the task of decreasing financial instability. Bank runs can happen with no relation to the levels of soundness and stability of a bank for the reasons of information asymmetry (Gorton, Huang, 2006), which considerably decreases the stability of the financial system during a financial crisis (Mishkin, 1999). Besides, the quality of management and regulation depends on both promptness and clarity of information on soundness and stability of banks. Decreasing levels of information asymmetry are achieved by providing the evaluation results in various formats understandable to all above-mentioned groups of decision-makers (Podviezko, 2012). The monitoring of the levels of soundness and stability of commercial banks by every criterion and by CAMEL categories of criteria could help not only bank management, but also comptrollers to take timely preventing and stabilising regulatory actions. The ranking of banks obtained by MCDA methods is one of the major clear and understandable formats available for providing decision-aid information for decision-makers.

The paper is structured as follows. In Section 2, following the Introduction, ten criteria for the evaluating the stability and soundness of the banks are described and the 2007-2009 statistical data, presenting the performance of eight Lithuanian banks is given. In Section 3, MCDA methods (SAW, COPRAS, TOPSIS, PROMETHEE II) and their main characteristics and features are described. In Section 4, the results of the evaluation of the stability and soundness of Lithuanian commercial banks, based on the use of each particular MCDA method, as well as the final ranking of the banks, the analysis of the evaluation results and the dynamics of the relative positions of the banks in the period of evaluation, are given. Finally, in Section 5 some concluding remarks are provided.

\section{II.VARIABLES AND DATA}

Contemporary research in the field of evaluating the commercial banks has been divided into two branches: one concentrating on macroprudential, another on microprudential variables (studies using both sets of variables are also found in the literature) (González-Hermosillo, 1999; Evans, Leone, Gill, Hilbers, 2000; Sufian, 2010). Banks operating in the same macroeconomical environment, under the Lithuanian Law on Banks were chosen for the present research.

The deposits of all above-mentioned banks are covered by the same deposit insurance scheme, provided by the State deposit insurance company of Lithuania „Deposit and Investment Insurance". Both business conditions of the considered banks, the methodology of evaluation proposed in this paper are uniform. The uniformity of the latter results from the use of the MCDA framework. This allows for evaluating all banks present in the market and operating in the same environment. Consequently, in this work the range of the influencing factors is limited the micro level.

Over the whole investigated period from 2007 to 2009, there were eight commercial banks registered in Lithuania: AB DnB NORD bankas (on 11 November, 2011 it was renamed to DNB bankas), UAB Medicinosbankas, $A B$ Parexbankas (on 26 August, 2010 it was renamed to $A B$ "Citadele" bankas), AB SEB bankas, AB Šiauliųbankas, AB bankas SNORAS, AB Swedbank and $A B$ Ükiobankas. 
To avoid subjectivity, we limit ourselves to quantitative evaluation of commercial banks. The banking business is complicated and so is the evaluation, which should reflect different aspects of bank activities. MCDA research must take into account a complete set of various types of criteria of soundness and stability of banks, describing major aspects of bank stability. The criteria should be of a limited number (Podviezko, Ginevicius, 2010). This may be achieved by dividing the criteria into core categories, thus creating a hierarchy, and then by filling each category with the best representative criteria, keeping in mind that the selected criteria should be non-overlapping, non-correlated, or in other words, not over-excessive. In addition, the categorisation of criteria facilitates the process of determining the weights. As we use the CAMEL approach, our criteria are intended to represent all five categories of soundness and stability as follows: Capital, Asset quality, Management, Earnings, and Liquidity. The criteria are listed in Table 2, indicating the respective ratios, the type of the criterion (which may be maximising or minimising), and the assigned weights. The weights were obtained by taking the average values of the weights elicited from seven experts in Lithuanian commercial banking. The statistical data obtained from the annual statements of the commercial banks registered in Lithuania are presented in Table 3.

TABLE 2. LIST OF CRITERIA DESCRIBING SOUNDNESS AND STABILITY OF COMMERCIAL BANKS

\begin{tabular}{|c|c|c|c|c|c|}
\hline Code & Category & $\begin{array}{l}\text { Cumulative } \\
\text { weights of } \\
\text { categories }\end{array}$ & Financial ratio & $\begin{array}{l}\text { Max } \\
\text { or Min }\end{array}$ & Weights \\
\hline CAPITAL & Capital & 0.223 & $\omega_{1} \cdot \operatorname{Tier} 1 / \mathrm{RWA}+\omega_{2} \cdot \operatorname{Tier} 2 / \mathrm{RWA}$ & + & 0.223 \\
\hline NII & Assets & 0.208 & Net interest income/RWA, $\%$ & + & 0.052 \\
\hline TL & & & Total loans/Total assets, \% & - & 0.052 \\
\hline DELINQ & & & Delinquent loans/Total assets, \% & - & 0.052 \\
\hline LD & & & $\begin{array}{l}\text { Loan value decrease/Total assets, } \\
\%\end{array}$ & - & 0.052 \\
\hline NIC & Management & 0.166 & Non-interest cost/Total income, \% & - & 0.166 \\
\hline РPP & Earnings & 0.225 & Pre-provision profit/RWA, \% & + & 0.153 \\
\hline $\mathrm{NI}$ & & & Net income/RWA, \% & + & 0.072 \\
\hline DEP & Liquidity & 0.178 & Total deposits/Total loans & + & 0.080 \\
\hline LIQ & & & Regulatory liquidity ratio, $\%$ & + & 0.098 \\
\hline
\end{tabular}

Notes: $\omega_{1}$ and $\omega_{2}$ are average weights assigned by experts to Tier 1 and Tier 2 ratios $\left(\omega_{1}=0.666\right.$, $\omega_{2}=0.334$ ); RWA denote risk-weighted assets, provided in annual statements.

Source: Authors'Estimations

Capital, represented by the first of the considered categories, serves as a buffer for absorption of possible losses of a bank. The bigger is the capital, the more it can absorb losses incepting out from bad loans, low cost and earning efficiency, as well as interest rate and FX fluctuations, trading, etc. While both Tier 1 and Tier 2 ratios in sum are forming the capital adequacy regulatory ratio, the two types of capital differ in riskiness. Naturally, experts assigned different weights $\omega_{1}, \omega_{2}$ of magnitude of contribution to soundness and stability of banks to these types of capital, namely 0.666 and 0.334 in average. For evaluation simplicity both values 
representing capital adequacy ratio were multiplied by corresponding weights and added together to form the variable CAPITAL.

Assets category is represented by four ratios. The first ratio presents the magnitude of net interest income, divided by RWA (risk-weighted assets). We believe that this is a better measure than that based on dividing interest income by total assets, since it corresponds to the riskadjusted return on capital measurement. A skewness of the ratios may appear because of an imprecise definition of risk categories of assets under Basel I framework, which was allowed to be used in Lithuania until the end of the transition period by the end of 2011. All the remaining ratios are common and obvious. The second is the ratio between loans, the most risky assets and total assets. The third ratio is delinquent loans to total assets. And finally, the last ratio within the category is the decrease of value of assets divided by total assets.

Management category is represented by a single ratio, expressing cost-efficiency of a bank. Since the aim of the research is to consider only quantitative financial criteria, we did not include the qualitative criteria to the analysis.

The category of earnings is represented by two ratios, which gauge pre-provision profits and net income, comparing them to risk-weighted assets. The first ratio reveals the capability of a bank to generate cash, which could then serve as a remedy for various losses, while the second ratio expresses remaining profits after all deductions have been made. The chosen ratios well agree with the findings of Wheelock and Wilson (2000): higher earnings, bigger capital ratios, cost-efficient management and better loan portfolio reduce a likehood of failure.

Finally, the last liquidity category is represented by the ratio between deposits and total loans, and the regulatory liquidity ratio imposed by the central bank, i.e. the Bank of Lithuania. In the former ratio, we chose the deposits represented only by customer deposits and excluded more volatile inter-bank deposits. The latter ratio indicates the short-term liquidity position of a bank within a month term.

TABLE 3. PERFORMANCE RATIOS OF COMMERCIAL BANKS REGISTERED IN LITHUANIA, \%

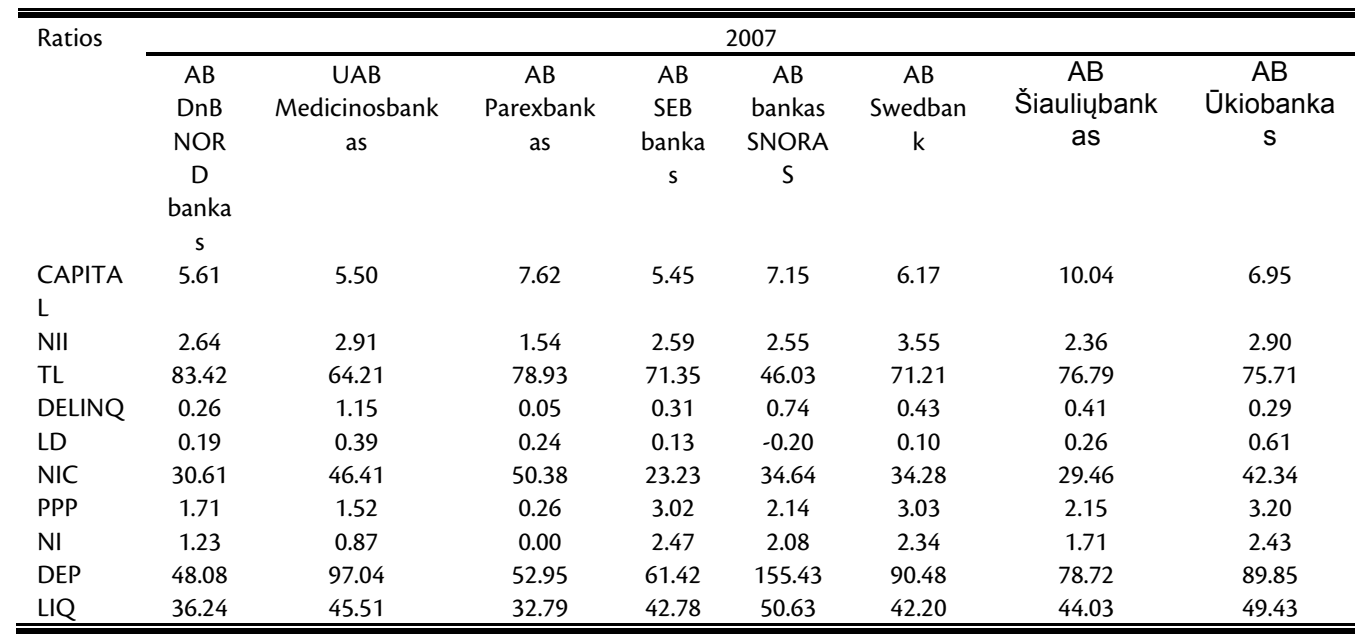




\begin{tabular}{|c|c|c|c|c|c|c|c|c|}
\hline \multirow[t]{2}{*}{ Ratios } & \multicolumn{8}{|c|}{2008} \\
\hline & $\begin{array}{c}\mathrm{AB} \\
\mathrm{DnB} \\
\mathrm{NOR} \\
\mathrm{D} \\
\text { banka } \\
\mathrm{s}\end{array}$ & $\begin{array}{c}\text { UAB } \\
\text { Medicinosbank } \\
\text { as }\end{array}$ & $\begin{array}{c}A B \\
\text { Parexbank } \\
\text { as }\end{array}$ & $\begin{array}{c}\mathrm{AB} \\
\mathrm{SEB} \\
\text { banka } \\
\mathrm{s}\end{array}$ & $\begin{array}{c}A B \\
\text { bankas } \\
\text { SNORA } \\
\text { S }\end{array}$ & $\begin{array}{c}A B \\
\text { Swedban } \\
k\end{array}$ & $\begin{array}{c}A B \\
\text { Šiauliųbank } \\
\text { as }\end{array}$ & $\begin{array}{c}A B \\
\text { Ūkiobanka } \\
s\end{array}$ \\
\hline $\begin{array}{l}\text { CAPITA } \\
\mathrm{L}\end{array}$ & 6.59 & 10.08 & 7.78 & 6.59 & 6.47 & 9.28 & 10.04 & 7.85 \\
\hline NII & 2.60 & 3.86 & 2.36 & 2.50 & 2.33 & 4.56 & 2.44 & 2.61 \\
\hline $\mathrm{TL}$ & 85.95 & 65.53 & 67.14 & 77.92 & 60.60 & 76.57 & 82.06 & 82.19 \\
\hline DELINQ & 1.06 & 8.39 & 0.26 & 1.14 & 3.00 & 1.10 & 0.69 & 1.29 \\
\hline LD & 0.50 & 1.21 & 0.84 & 0.59 & 0.67 & 0.25 & 0.36 & 0.72 \\
\hline NIC & 24.62 & 36.27 & 43.99 & 21.87 & 34.33 & 29.14 & 25.73 & 36.77 \\
\hline PPP & 1.58 & 2.20 & -0.05 & 2.35 & 1.54 & 3.78 & 1.54 & 2.53 \\
\hline $\mathrm{NI}$ & 0.62 & 0.85 & -1.67 & 1.49 & 0.51 & 2.92 & 1.00 & 1.57 \\
\hline DEP & 34.27 & 102.62 & 29.86 & 50.72 & 113.17 & 72.06 & 74.90 & 87.93 \\
\hline LIQ & 37.47 & 59.43 & 32.93 & 38.99 & 36.37 & 39.76 & 38.75 & 42.45 \\
\hline
\end{tabular}

Source: Authors'Estimations

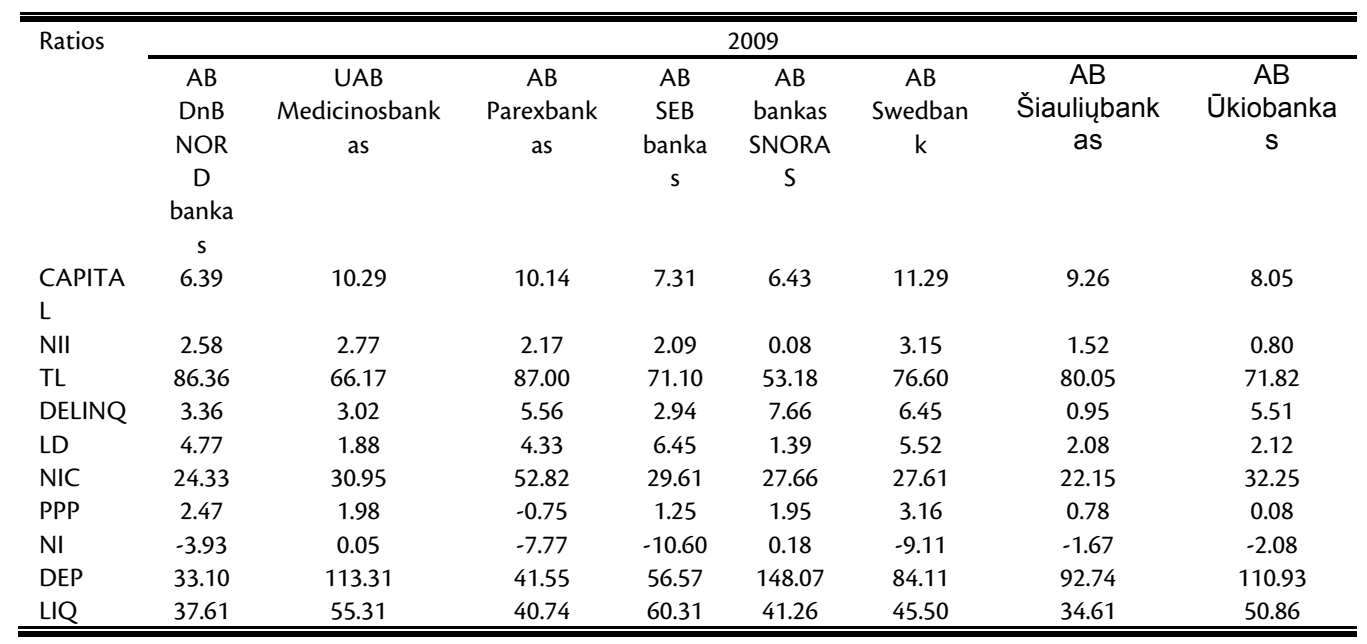

Source: Authors'Estimations

Table 3 can give some basic idea of the relative soundness and stability position of banks and be used in thorough evaluation of banks based on each criterion. However, the following shortcomings of this type of evaluation can be listed:

- weights of criteria are not accounted for;

- integrating relative positions of banks into a single criterion of soundness and stability is still an overwhelming task;

- distortion of data mostly referring to the categories, where data is often imprecise (e.g. within the assets and earnings categories, where data often strongly depends on the accounting policies of a bank) is not taken into consideration.

Nevertheless, the criteria values are perfect to show the levels of riskiness of a bank with respect to every criterion, particularly, when the level of soundness and stability a bank is relatively low. Even at this stage it is possible to make conclusions by considering data in Table 3. 
Final rankings of the banks reflecting their evaluation by all MCDA methods will appear at the end of Section 4.

\section{III.THE APPLIED METHODS}

Compromising of the following intrinsic conflicts between the goals for optimising the values of criteria observed within the categories is facilitated by the MCDA approach. For example, the variables under the category of assets standing for the quality of loans are set, taking into account the objective of maximal safety of bank assets (in terms of our analysis), while the variables under the category of earnings are set to account for the objective of increasing profits, which usually implies an increase of assets risk. Another conflict is between the goals set for the variables under the category of liquidity and efficiency, since liquid assets usually generate lower yields. MCDA methods are designed to cope with the task of evaluation, when the goals are conflicting. Different MCDA methods were chosen and applied to the analysis of the financial data for 2007, 2008, and 2009 contained in the financial statements of the commercial banks registered in Lithuania. Each method yields rankings of the banks. The dynamics of soundness and stability of the banks is demonstrated. Based on the cumulative criterion of all MCDA methods used, the ranking tables of banks will be created.

There is no single best MCDA method, which guarantees precision of evaluation. Each MCDA method has its specific features and logic, therefore discrepancies in the results of evaluation obtained by each method may occur. Only the simultaneous use of several MCDA methods can increase the reliability of the results. In this paper, some popular MCDA methods, such as SAW, and TOPSIS, as well as created in Lithuania method COPRAS and more sophisticated PROMETHEE II method with deeper intrinsic logic are used. The average of cumulative criteria for each bank obtained by using each of the above-mentioned methods is finally taken, which provides a basis for the final ranking of the considered banks. The dynamics of the positions of the banks in the market in the period of 2007-2009 is shown in Table 6.

The MCDA methods use a decision matrix containing the statistical data or experts' assessment data $\mathbf{R}=\left\|r_{i j}\right\|$ characterising the objects being evaluated, and weights of criteria $\omega_{i}$ ( $\left.\sum_{i=1}^{n} \omega_{i}=1\right), i=1,2, \ldots, m ; j=1,2, \ldots, n$, where $m$ is the number of criteria, $n$ is the number of the evaluated objects or alternatives, outlined in Table 3. Every criterion must be defined as maximising or minimising. The maximum values of maximising criteria are considered to be the best, while the minimum values are the best for minimising criteria.

\section{A. THE SAW METHOD.}

The SAW (Simple Additive Weighting) (Hwang, Yoon, 1981; Ginevicius, Podvezko, Bruzge, 2008) method is the oldest most widely known and practically used MCDA method. The method was applied after normalisation of data (Ginevicius, Podvezko, 2009) and after transformation of values in case if there are negative ones (Ginevicius, Podvezko, 2007). The results of evaluation $S_{j}$ are expressed in convenient relative values making the unity in the total $\sum_{j=1}^{n} S_{j}=1$. The 
alternatives could be ranked in the decreasing order in accordance with the value of the cumulative criterion of the method $S_{j}$.

\section{B. THE COPRAS METHOD.}

The COPRAS (Complex Proportional Assessment) method was created in 1996 and quickly became popular (Ginevicius, Podvezko, 2008b;Zavadskas, Turskis, 2011; Podvezko, 2011; Kildienè, Kaklauskas, Zavadskas, 2011). This method, unlike previously described methods uses both minimising and maximising criteria and does not require the transformation of the former into the maximising ones. The cumulative criterion of this method has two components, where one of them $S_{+j}$, is designed to comprise the maximising criteria, and is identical to the respective additive of the cumulative criterion of the SAW method $S_{j}$.

The cumulative criterion of the COPRAS method is expressed by the following formula:

$$
Z_{j}=S_{+j}+\frac{S_{-\min } \sum_{j=1}^{n} S_{-j}}{S_{-j} \sum_{j=1}^{n} \frac{S_{-\min }}{S_{-j}}}
$$

where

$$
S_{+j}=\sum_{i=1}^{m} \omega_{+i} \rho \text { \% represents the contribution of the } j \text {-th alternative's maximising }
$$

weighted values of criteria $\widetilde{r}_{+i j}$, normalised in accordance with the formula (2), to the cumulative criterion of the method.

The contribution of minimising criteria is represented by the other component, where $S_{-j}=\sum_{i=1}^{m} \omega_{-i} \rho \%$, which is $j$-th alternative's weighted sum of minimising values of criteria $P \%$, normalised in accordance with the formula (2). $S_{-\min }=\min _{j} S_{-j}$ is the minimal value of all minimising criteria.

\section{THE TOPSIS METHOD.}

The TOPSIS (Technique for Order Preference by Similarity to an Ideal Solution) (Opricovic, Tzeng, 2004) method has its unique exciting idea and therefore is one of the most interesting and therefore popular. The alternative is considered as the best solution in the case when the distance to the best hypothetical solution $V *$ is the shortest, while the distance to the worst hypothetical solution $V^{-}$is the largest. The method could be directly applied without the transformation of 
minimising criteria into the maximising ones. Normalisation of the criteria in the TOPSIS method transforms a vector to the unit vector by the following formula:

$$
\widetilde{r}_{i j}=\frac{r_{i j}}{\sqrt{\sum_{j=1}^{n} r_{i j}^{2}}}(i=1, \ldots, m ; j=1, \ldots n),
$$

where $\widetilde{r}_{i j}$ is the normalised value of the $i$-th criterion for the $j$-th alternative.

The distances of each $i$-th alternative to the best hypothetical solution and to the worst hypothetical solution are calculated as follows:

$$
\begin{gathered}
D_{j}^{*}=\sqrt{\sum_{i=1}^{m}\left(\omega_{i} \widetilde{r}_{i j}-V_{i}^{*}\right)^{2}} \\
D_{j}^{-}=\sqrt{\sum_{i=1}^{m}\left(\omega_{i} \tilde{r}_{i j}-V_{i}^{-}\right)^{2}}
\end{gathered}
$$

The cumulative criterion $C_{j}^{*}\left(0 \leq C_{j}^{*} \leq 1\right)$ of the TOPSIS method is calculated in this way:

$$
C_{j}^{*}=\frac{D_{j}^{-}}{D_{j}^{*}+D_{j}^{-}} \quad(j=1,2, \ldots, n)
$$

Ranking is made in the decreasing order in accordance with the values of the cumulative criterion of the TOPSIS method. The highest value of the criterion corresponds to the best alternative, and its lowest value corresponds to the worst alternative.

\section{THE PROMETHEE METHOD}

The PROMETHEE (Preference Ranking Organisation Method for Enrichment Evaluation) methods (Brans, Mareschal, Vincke 1986; Figueira, Greco, Ehrgott, 2005) differ from other multicriteria methods by the depth of their intrinsic logic and by the use of the preference functions, which make a basis of the methods. The shapes of the functions and their parameters are chosen by decision-makers. The PROMETHEE methods integrate the values of the selected criteria and their weights in a more sophisticated way by using preference functions with few 
parameters. The shapes of the preference function and their parameters are chosen by the persons responsible for evaluation, i.e. by decision-makers or qualified experts.

The PROMETHEE methods use the values of the so-called preference functions $p(d)$ rather than normalised values of the criteria $\widetilde{r}_{i j}$. The values of the functions account for the level of preference of one alternative over another. This ensures clear advantages of the method over other approaches. The need for transforming the minimising criteria into the maximising ones, and, what is more important, the negative values of the criteria into the positive ones in the process of data normalisation is eliminated.

The shapes of the functions, as well as boundary parameters $q$ and $s$ for each criterion $i$, are chosen by decision-makers, e.g. $q_{i}$ is chosen for the lower and $s_{i}$ - for the upper boundary of the argument, where the preference function ranges in the interval $0<p(d)<1$ (Podvezko and Podviezko, 2010a,b). A single type $V$-shape with the indifference preference function was chosen for all the criteria to reflect the proportional preference for the alternatives compared, wherever $d_{i}\left(A_{j}, A_{k}\right)$ falls between the parameters $q_{i}$ and $s_{i}$ :

$$
p_{i}(d)=\left\{\begin{array}{l}
0, \text { when } d_{i} \leq q_{i} \\
\frac{d_{i}-q_{i}}{\mathrm{~s}_{i}-q_{i}}, \text { when } \mathrm{q}_{i}<d_{i} \leq s_{i} \\
1, \text { when } d_{i}>s_{i}
\end{array}\right.
$$

We obviously use the advantage of the PROMETHEE II method and set different degrees of tolerance for obtaining the levels of indifference, depending on the degree of precision of data given. For example, the data on the deterioration of loan portfolio strongly depends on the accountancy method used by each bank and is therefore rather imprecise. The liquidity ratio LIQ imprecision is highlighted by another argument: it reflects the bank's liquid position only within a month's period. On the other hand, the data on the capital, for example, has a much higher degree of precision. Parameters $q$ and $s$ for each criterion $i$ and the year of the analysed period are obtained in accordance with the algorithm described in Podvezko and Podviezko (2010a). The values of the parameters $q_{i}$ and $s_{i}$ are presented in Table 4 
TABLE 4. THE VALUES OF THE PARAMETERS $Q_{1}$ AND $S_{\text {I }}$

\begin{tabular}{lcccccc}
\hline \hline \multirow{1}{*}{ Code } & \multicolumn{2}{c}{2007} & & \multicolumn{2}{c}{2008} & \multicolumn{2}{c}{2009} \\
\cline { 2 - 7 } CAPITAL & $q_{i}$ & $s_{i}$ & $q_{i}$ & $s_{i}$ & $q_{i}$ & $s_{i}$ \\
NII & 0.20 & 4.46 & 0.11 & 3.50 & 0.18 & 4.75 \\
TL & 0.11 & 1.91 & 0.13 & 2.11 & 0.23 & 2.92 \\
DELINQ & 0.05 & 2.11 & 0.16 & 2.11 & 0.23 & 2.11 \\
LD & 0.05 & 1.06 & 0.28 & 7.89 & 0.25 & 6.51 \\
NIC & 0.11 & 0.72 & 0.16 & 0.85 & 0.64 & 4.46 \\
PPP & 1.71 & 25.82 & 1.59 & 21.04 & 1.59 & 29.14 \\
NI & 0.16 & 2.80 & 0.19 & 3.64 & 0.23 & 3.71 \\
DEP & 0.16 & 2.35 & 0.30 & 4.36 & 0.66 & 10.24 \\
LIQ & 3.83 & 104.16 & 5.26 & 80.90 & 5.76 & 111.59 \\
\hline \hline
\end{tabular}

Source: Authors'Estimations

The PROMETHEE II method yields the cumulative criterion of evaluation $F_{j}$. The method ranges the alternatives in the decreasing order in respect of the values $F_{j}$.

The authors also obtained the results for the same group of banks using the PROMETHEE I method. The results obtained using the PROMETHEE II method match the results yielded by the PROMETHEE I method, which is designed only to indicate the best alternative.

\section{THE RESULTS OBTAINED.}

The evaluation of the banks in terms of soundness and stability was made by four MCDA methods: SAW, TOPSIS, COPRAS, and PROMETHEE II, using the formulas (1)-(13). The methods generated cumulative criteria, representing a relative level of soundness and stability of banks, which then were used to perform the ranking of banks by each method. The results (presented in Table 5) demonstrated rather good concordance. The correlation coefficients between all pairs of cumulative criteria obtained by MCDA methods range from 0.98 to 0.80 , which shows a very good agreement. Insignificant exceptions reinforce the statement that several MCDA methods should be used simultaneously in order to increase the reliability of the result. 
TABLE 5. THE RESULTS OF EVALUATION OF STABILITY AND SOUNDNESS OF LITHUANIAN COMMERCIAL BANKS IN THE PERIOD OF 2007-2009

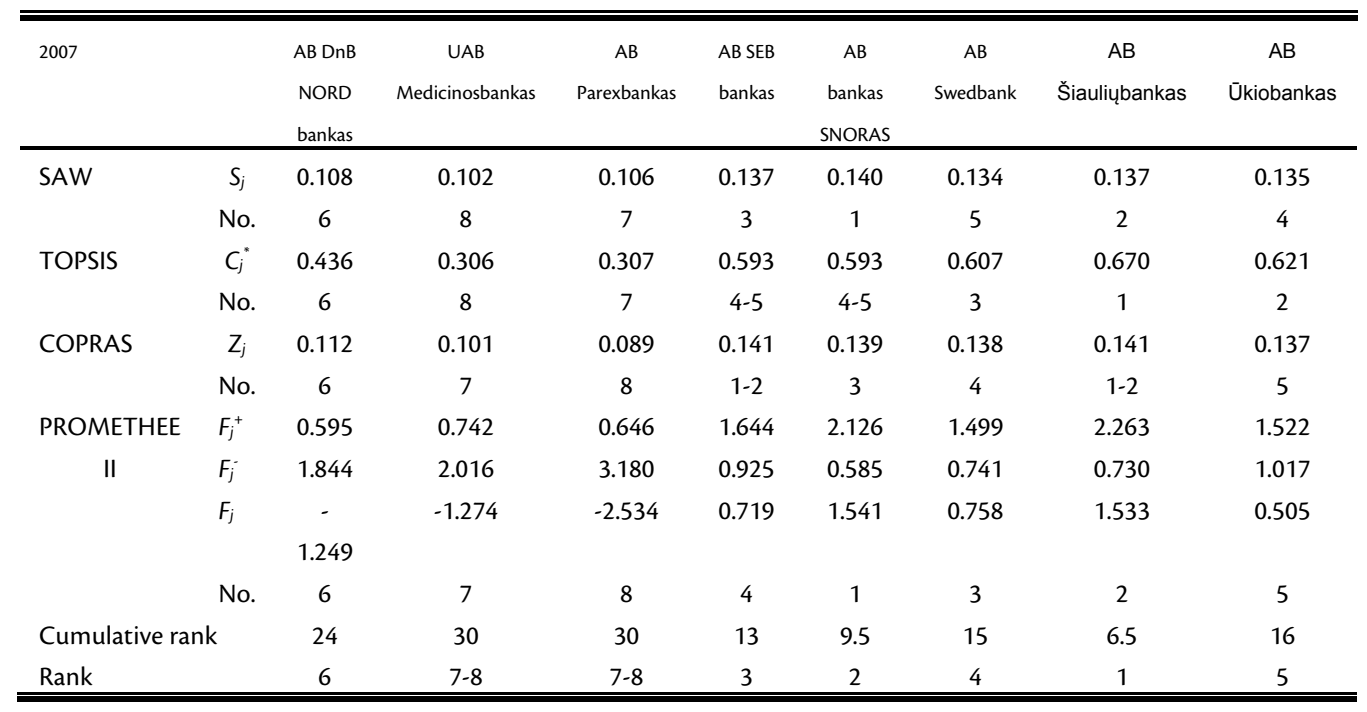

Source: Authors'Estimations

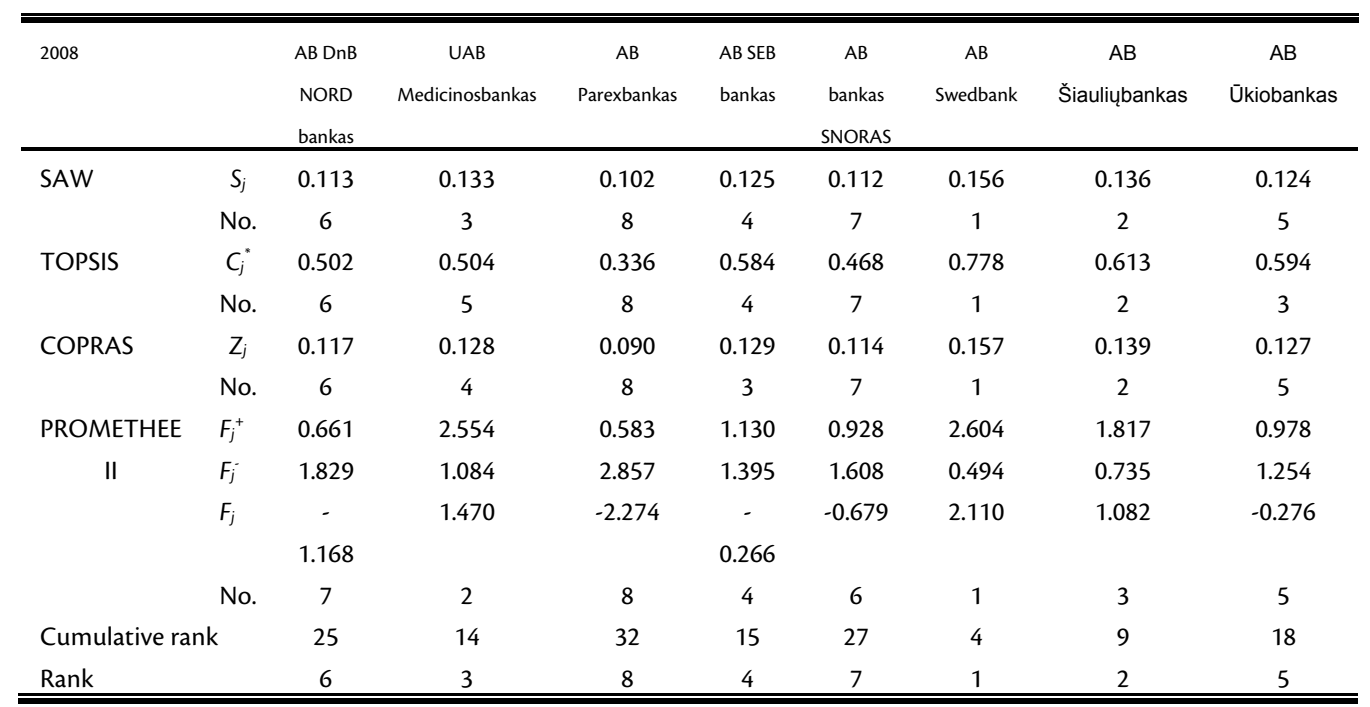

Source: Authors'Estimations 


\begin{tabular}{|c|c|c|c|c|c|c|c|c|c|}
\hline \multicolumn{2}{|l|}{2009} & \multirow{2}{*}{$\begin{array}{l}\text { AB DnB } \\
\text { NORD } \\
\text { bankas }\end{array}$} & \multirow{2}{*}{$\begin{array}{c}\text { UAB } \\
\text { Medicinosbankas }\end{array}$} & \multirow{2}{*}{$\begin{array}{c}\mathrm{AB} \\
\text { Parexbankas }\end{array}$} & \multirow{2}{*}{$\begin{array}{l}\text { AB SEB } \\
\text { bankas }\end{array}$} & \multirow{2}{*}{$\begin{array}{c}\mathrm{AB} \\
\text { bankas } \\
\text { SNORAS } \\
\end{array}$} & \multirow{2}{*}{$\begin{array}{c}A B \\
\text { Swedbank }\end{array}$} & \multirow{2}{*}{$\begin{array}{c}\text { AB } \\
\text { Šiauliųbankas }\end{array}$} & \multirow{2}{*}{$\begin{array}{c}\text { AB } \\
\text { Ūkiobankas }\end{array}$} \\
\hline & & & & & & & & & \\
\hline \multirow[t]{2}{*}{ SAW } & $S_{j}$ & 0.119 & 0.151 & 0.091 & 0.110 & 0.133 & 0.137 & 0.145 & 0.115 \\
\hline & No. & 5 & 1 & 8 & 7 & 4 & 3 & 2 & 6 \\
\hline \multirow[t]{2}{*}{ TOPSIS } & $C_{j}^{*}$ & 0.554 & 0.804 & 0.299 & 0.470 & 0.570 & 0.664 & 0.614 & 0.478 \\
\hline & No. & 5 & 1 & 8 & 7 & 4 & 2 & 3 & 6 \\
\hline \multirow[t]{2}{*}{ COPRAS } & $Z_{j}$ & 0.119 & 0.158 & 0.093 & 0.109 & 0.128 & 0.136 & 0.140 & 0.117 \\
\hline & No. & 5 & 1 & 8 & 7 & 4 & 3 & 2 & 6 \\
\hline PROMETHEE & $\mathrm{F}_{j}^{+}$ & 0.954 & 2.400 & 0.766 & 1.188 & 1.565 & 2.186 & 1.579 & 1.202 \\
\hline \multirow[t]{3}{*}{ II } & $F_{j}$ & 1.906 & 0.294 & 2.865 & 1.691 & 1.516 & 0.999 & 1.159 & 1.409 \\
\hline & $F_{j}$ & -0.952 & 2.107 & -2.099 & -0.503 & 0.049 & 1.186 & 0.420 & -0.207 \\
\hline & No. & 7 & 1 & 8 & 6 & 4 & 2 & 3 & 5 \\
\hline \multicolumn{2}{|c|}{ Cumulative rank } & 22 & 4 & 32 & 27 & 16 & 10 & 10 & 23 \\
\hline \multicolumn{2}{|l|}{ Rank } & 5 & 1 & 8 & 7 & 4 & $2-3$ & $2-3$ & 6 \\
\hline
\end{tabular}

Notes: $S_{j}, C_{j}^{*}, Z_{j}$, are the cumulative criteria of the respective SAW, COPRAS and TOPSIS methods, $F_{j}^{+}$, $F_{j}$ are "outgoing" and "incoming" ranking cumulative indices, $F_{j}$ is the cumulative criteria of the PROMETHEE method, No.is the outranking position determined by each method, Cumulative rank is the sum of ranks obtained by each method, Rank is the cumulative outranking position

Source: Authors'Estimations

The final ranking is presented in Table 6.

TABLE 6. AVERAGE RELATIVE SOUNDNESS AND STABILITY POSITIONS OF LITHUANIAN COMMERCIAL BANKS IN 2007-2009

\begin{tabular}{ccccccccc}
\hline \hline & $\begin{array}{c}\text { AB DnB } \\
\text { NORD } \\
\text { bankas }\end{array}$ & $\begin{array}{c}\text { MAB } \\
\text { Medicinosbankas }\end{array}$ & $\begin{array}{c}\text { AB } \\
\text { Parexbankas }\end{array}$ & $\begin{array}{c}\text { AB SEB } \\
\text { bankas }\end{array}$ & $\begin{array}{c}A B \\
\text { bankas } \\
\text { SNORAS }\end{array}$ & $\begin{array}{c}\text { AB } \\
\text { Swedbank }\end{array}$ & $\begin{array}{c}\text { AB } \\
\text { Siauliubankas }\end{array}$ & $\begin{array}{c}\text { AB } \\
\text { Ukiobankas }\end{array}$ \\
\hline 2007 & 6 & $7-8$ & $7-8$ & 3 & 2 & 4 & 1 & 5 \\
2008 & 6 & 3 & 8 & 4 & 7 & 1 & 2 & 5 \\
2009 & 5 & 1 & 8 & 7 & 4 & $2-3$ & $2-3$ & 6 \\
\hline \hline
\end{tabular}

Source: Authors'Estimations

The market of Lithuanian commercial banks in terms of soundness and stability appears to comprehend a considerable portion of instability and turbulence of the emerging market. Due to this instability, it seems impossible to disaggregate the considered banks into categories according to the levels of their soundness and stability. The banks once appearing to be most stable yield their positions to other banks. Only two banks AB Šiauliubankas and AB Swedbank, could be assigned to the upper-stability group. In addition, $A B$ Parexbankas steadily exhibited the tardiness over the considered period. More detailed examination based on the key factors influencing soundness and stability positions of commercial banks is provided in Podviezko (2012). 


\section{CONCLUSIONS}

The successful development of economy is based on effective and stable performance of commercial banks, as the analysis of performance of the financial system of Lithuania revealed that it is bank-based. The evaluation of stability and soundness of banks is a complex task, requiring the use of a number of multi-dimensional criteria. MCDA methods are well suited for solving such problems, especially in the cases, when data is too scarce to use statistical methods.

MCDA methodology was applied to the financial data of the period from 2007 to 2009 reported by all eight commercial banks registered in Lithuania. The methodology is based on the comparison of the financial performance ratios and ultimately yields the relative levels of soundness and stability of commercial banks in the form of annual rankings, based on which the dynamics of soundness and stability of commercial banks can be observed. Several MCDA methods, including SAW, TOPSIS, COPRAS and PROMETHEE II were used in the investigation. The latter method does not require the transformation of data with negative values, which was very useful for the present analysis. Another very useful feature of the method was used in the methodology, such as degrees of tolerance, which create levels of indifference, depending on the degree of precision of data given.

The evaluation based on the described methodology is very important for the clients of the banks, for regulatory purposes, and for banks' management, since the format of the results, presented both as the ranking tables, and by the average values of the cumulative criteria obtained by using the above-mentioned different MCDA methods is understandable by the considered groups of users. The former type of presentation indicates a general position of the bank in the market in terms of its soundness and stability, while the latter more precisely expresses a relative position of banks in real numbers. The requirement for developing more formats for presenting the results obtained by using MCDA methods, which can demonstrate the causes of either the prominence or lagging of a bank has been raised in the paper. In the fluctuating market, MCDA provides the opportunity of prompt evaluation, allowing for rapid reaction of bank management or comptrollers to the situation.

The deviations in the results, obtained by using different MCDA methods, were found to be insignificant, as correlation of values between the cumulative criteria of each method are ranging from 0.8 to 0.98 . Precision of the ultimate result was increased by taking the average of the cumulative criteria. Additional considerations explaining the application of different MCDA methods and the average stem from the well-known fact that the best MCDA method cannot be identified. This approach reduces the model risk found in the cases, when unacceptable distortions of the results obtained by using different methods can be observed.

The evaluation results revealed certain instability of Lithuanian commercial bank market. First, a clear leader, i.e. the most stable bank has not been found. Second, the fluctuations of the positions of the banks were considerable over the period analysed. Relative soundness and stability positions of two banks drastically changed over the period of investigation. For example, from the last place to the leading place (UAB Medicinosbankas) and from the highest position to the bottom position (AB SEB bankas).

For increasing the reliability of the results additional statistical methods could be used when the extensive statistical data have been obtained. The using other MCDA methods such as UTA, DEA, ELECTRE III, IV, MUSA, and DEA should increase the reliability as well. The classification of banks into the categories representing reliable, sufficiently reliable and relatively weak banks, using the methods M.H.DIS, UTADIS I,II,III, ELECTRE TRI, RANGU, ROSE, PREFDIS 
and others could further increase the reliability of the obtained results as well. Moreover, the latter results would serve as an additional valuable reporting tool for the groups of users involved in the evaluation.

\section{REFERENCES}

Brans, J.-P., Mareschal, B., Vincke, P., (1986), "How to select and how to rank projects: The PROMETHEE method",European Journal of Operational Research, 24(2): 228-238.

Brauers, W. K., Ginevicius, R., Podviezko, A., (2012), "Evaluation of performance of Lithuanian commercial banks by multi-objective optimization". In R. Ginevicius, A. V. Rutkauskas, J. Stankeviciene (Eds.), The 7th International Scientific Conference Business and Management'2012. Selected papers (pp. 1042-1049), (Vilnius, Lithuania: Technika).

Ergungor, O. E., Thomson, J. B., (2005), "Systemic banking crises", Policy Discussion Papers: 1-13.

Evans, O., Leone, A. M., Gill, M., Hilbers, P. (Eds.), (2000), "Macroprudential Indicators of Financial System Soundness", International Monetary Fund Occasional Paper, 192:1-49.

Figueira, J., Greco S., Ehrgott, M. (eds.), (2005), Multiple Criteria Decision Analysis: State of the Art Surveys, (New York: Springer).

Ginevicius, R., Podvezko, V., (2007), "Some problems of evaluating multicriteria decision methods", International Journal of Management and Decision Making, 8 (5/6):527-539.

Ginevicius, R., Podvezko, V., (2008a), "Multicriteria evaluation of Lithuanian banks from the perspective of their reliability for clients", Journal of Business Economics and Management, 9(4):257-267.

Ginevicius, R., Podvezko, V., (2008b), "Housing in the context of economic and social development of Lithuanian regions", Int. J. Environment and Pollution, 35(2/3/4):309-330.

Ginevicius, R., Podvezko, V., (2009), "Evaluating the changes in economic and social development of Lithuanian counties by multiple criteria methods", Technological and Economic Development of Economy, 15(3):418-436.

Ginevicius, R., Podvezko, V., Bruzge, S., (2008), "Evaluating the Effect of State Aid to Business by Multicriteria Methods", Journal of Business Economics and Management, 9(3):167180.

Ginevicius, R., Podvezko, V., Novotny, M., (2010), "Evaluating Lithuanian banks from the perspective of their reliability to customers by PROMETHEE method". In R. Ginevicius, A. V. Rutkauskas, and R. Pocs (Eds.), The 6th International Scientific Conference Business and Management'2010: Selected papers (pp. 993-999), (Vilnius, Lithuania: Technika).

Ginevicius, R., Podvezko, V., Podviezko, A., (2012), In R. Ginevicius, A. V. Rutkauskas, J. Stankeviciene (Eds.), The 7th International Scientific Conference Business and Management'2012. Selected papers (pp. 1083-1089), (Vilnius, Lithuania: Technika). 
González-Hermosillo, B., (1999), “Determinants of Ex-Ante Banking System Distress: A Macro-Micro Empirical Exploration of Some Recent Episodes", IMF Working Paper, 99/33:1 - 144.

Gorton, G., Huang, L., (2006), "Bank panics and the endogeneity of central banking", Journal of Monetary Economics, 53(7):1613 - 1629.

Hwang, C.L., Yoon, K., 1981, Multiple Attribute Decision Making-Methods and Applications: A State of the Art Survey, (Berlin, Heidelberg, New York: Springer).

Kildienè, S., Kaklauskas, A., Zavadskas, E. K., (2011), “COPRAS based Comparative Analysis of the European Country Management Capabilities within the Construction Sector in the Time of Crisis", Journal of Business Economics and Management, 12(2):417-434.

Miletic, I., (2009), "Macroeconomic and Microeconomic Causes for the Instability of Banks", Economic Research, 22(1):47-59.

Mishkin, F. S., (1999), “Global Financial Instability: Framework, Events, Issues”, Journal of Economic Perspectives, 13(4):3-20.

Opricovic, S., Tzeng,G.-H., (2004), "Compromise solution by MCDM methods: A comparative analysis of VIKOR and TOPSIS", European Journal of Operational Research, 156:445455 .

Podvezko, V., (2011), "The Comparative Analysis of MCDA Methods SAW and COPRAS", InzinerineEkonomika-Engineering Economics, 22(2):134-146.

Podviezko, A., (2012), "Augmenting Multicriteria Decision Aid Methods by Graphical and Analytical Reporting Tools". In L. Niedrite, R. Strazdina, and B. Wangler (Eds.), Workshops on Business Informatics Research, Lecture Notes in Business Information Processing (Vol. 106, pp. 236251), (Berlin, Heidelberg: Springer).

Podviezko, A., Ginevicius, R., (2010), "Economic criteria characterising bank soundness and stability". In R. Ginevicius, A. V. Rutkauskas and R. Pocs (Eds.), The 6th International Scientific Conference Business and Management'2010: Selected papers (pp. 1072-1079), (Vilnius, Lithuania: Technika).

Spronk, J., Steuer, R. E., Zopounidis, C., (2005), "Multicriteria Decision Aid: Analysis in Finance". In J. Figueira, M. Ehrgott and S. Greco (Eds.), Multiple Criteria Decision Analysis:State of the Art Surveys (pp. 799-857), (New York: Springer).

Stankeviciene, J., Mencaite, E., (2012), "The evaluation of bank performance using a multicriteria decision making model: a case study on Lithuanian commercial banks", Technological and Economic Development of Economy, 18(1):189-205.

Sufian, F., (2010), "Assessing the Impact of Financial Sector Restructuring on Bank Performance in a Small Developing Economy", Economic Research, 23(2):11-34.

White, L., Smith, H., Currie, C., (2011), "OR in developing countries: A review",European Journal of Operational Research, 208:1-11.

Zavadskas, E.K., Kaklauskas, A., Banaitis, A., Kvederyte, N., (2006), “Housing credit access model: The case for Lithuania", European Journal of Operational Research, 155:335-352. 
Zavadskas, E. K., Turskis, Z., (2011), "Multiple criteria decision making (MCDM) methods in economics: an overview", Technological and Economic Development of Economy, 17(2):397-427.

Zopounidis, C., (1999), "Multicriteria decision aid in Financial management", European Journal of Operational Research, 119:404-415.

Zvirblis, A., Buracas, A.,(2010), "The consolidated measurement of the financial markets development: The case of transitional economies", Technological and Economic Development of Economy, 16(2):266-279

\title{
EVALUACIJA STABILNOSTI TRŽIŠTA I SIGURNOST LITVANSKIH BANAKA
}

\begin{abstract}
SAŽETAK
Uspješan razvoj ekonomije se bazira na učinkovitom i stabilnom poslovanju komercijalnih banaka. Evaluacija stabilnosti i sigurnosti banaka je složen zadatak koji uključuje znatan broj multidimenzionalnih kriterija. To je i idiosinkratski zadatak radi komplicirane interne strukture banaka, isprepletenih tokova novca i snažnog utjecaja stanja na tržištu na razine sigurnosti. $U$ ovom radu se procjenjuje dinamika sigurnosti i stabilnosti komercijalnih banaka registriranih u Litvi uz pomoć nekoliko metoda s višestrukim kriterijima, od jednostavnih do sofisticirane PROMETHEE metode. Dobiveni rezultati upućuju na to da su razine sigurnosti i stabilnosti banaka koje posluju na novonastalom litvanskom tržištu komercijalnih banaka uočljivo fluktuirajuće. Usporedba dobivenih rezultata otkriva uzroke fluktuacija. Istovremeno korištenje različitih kriterija u metodama procjene sigurnosti i stabilnosti komercijalnih banaka povećava čvrstinu procjene.
\end{abstract}

Ključne riječi: analiza višestrukih kriterija, OR u bankarstvu, sigurnost i stabilnost banaka, CAMEL 
Romualdas Ginevičius, Askoldas Podviezko

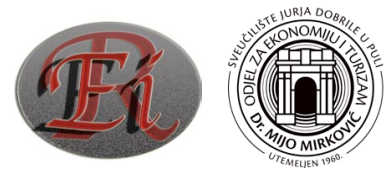

